\title{
CD73/5'-ECTO-NUCLEOTIDASE ACTS AS A REGULATORY FACTOR IN OSTEO-/CHONDROGENIC DIFFERENTIATION OF MECHANICALLY STIMULATED MESENCHYMAL STROMAL CELLS
}

\author{
Andrea Ode ${ }^{1,2 *}$, Janosch Schoon ${ }^{1,2}$, Annett Kurtz ${ }^{1}$, Marcel Gaetjen ${ }^{1}$, Jan E. Ode ${ }^{1}$, Sven Geissler ${ }^{1,2}$, Georg N. Duda ${ }^{1,2}$ \\ ${ }^{1}$ Julius Wolff Institute and Musculoskeletal Research Center Berlin, Charité-Universitätsmedzin, Berlin, Germany \\ ${ }^{2}$ Berlin-Brandenburg Center for Regenerative Therapies, Berlin, Germany
}

\begin{abstract}
Bone regeneration is influenced by mesenchymal stromal cells (MSCs) and mechanical conditions. How healing outcome and mechanical stability are linked on the cellular level, however, remains elusive. Cyclic-compressive loading of MSCs affects the expression of molecules involved in angiogenesis and matrix assembly, but also reduces the expression of $\mathrm{CD} 73$, an ecto-5'-nucleotidase, which plays a crucial role in extracellular adenosine generation. Although, for almost 20 years, CD73 has been a major cell surface marker defining MSCs, little is known about its function in these cells. Therefore, the aim of this study was to determine the putative involvement of CD73 in MSC differentiation after cyclic-compressive loading. After cultivation in appropriate differentiation media, chondrogenic differentiation ability was significantly increased in loaded MSCs, hence following current models. Through treatment with the CD73 inhibitor adenosine 5 '-( $\alpha, \beta$-methylene) diphosphate, chondrogenic matrix deposition was further increased; in contrast, mineral matrix deposition and expression of osteogenic markers was reduced. One major signal transduction pathway, which is activated via CD73-mediated adenosine, is the adenosine receptor pathway. Thus, the adenosine receptor expression pattern was investigated. MSCs expressed the four known adenosine receptors at the mRNA level. After mechanical stimulation of MSCs, Adora $2 a$ was down-regulated. These data point towards a role of CD73 in MSC differentiation possibly via A2AR signalling, which is mutually regulated with CD73. In conclusion, the findings of this study suggest that CD73 is another regulatory factor in osteo-/ chondrogenic differentiation of MSCs and may provide a - thus far underestimated - therapeutic target to guide bone regeneration.
\end{abstract}

Keywords: Mesenchymal stromal cells; mechanical stimulation; CD73/5'-ecto-nucleotidase; chondrogenic differentiation; osteogenic differentiation.

*Address for correspondence:

Andrea Ode,

Julius Wolff Institute and Center for Musculoskeletal Surgery,

Charité-Universitätsmedizin Berlin,

Augustenburger Platz 1,

13353 Berlin

Germany

Telephone Number: +49 (030) 450659097

Fax Number: +49(030) 450559969

E-mail: Andrea.Ode@charite.de

\section{Introduction}

Bone healing is a complex, however well-orchestrated, multistage regenerative process. Bone fracture coincides with disruption of blood vessels resulting in activation of the coagulation cascade and formation of the haematoma, which encloses the fracture area. Inflammatory cells, fibroblasts, and mesenchymal stromal cells (MSCs) are recruited to the site. Once MSCs have reached the bone fracture site they are confronted with a challenging milieu characterised not only by inflammatory cytokines and low oxygen tension (hypoxia) but also by constant mechanical strain (Goodship and Kenwright, 1985; Komatsu and Hadjiargyrou, 2004). This condition is likely to affect MSCs, which are known to be mechanosensitive (Wang and Thampatty, 2008). Thus, detailed knowledge about the influence of mechanical loading on MSCs is pivotal for understanding the physiological processes during bone regeneration in order to develop innovative cell therapy approaches.

Recently, we and others provided evidence that mechanical strain leads to reduced expression of the cell surface marker CD73 in vitro (Kang et al., 2011; Ode et al., 2011). In our study, bone marrow (BM)-MSCs underwent cyclic-compressive loading for three days. CD73 protein and mRNA expression were significantly reduced. Of note, this effect persisted for a week after removal of the loading stimulus (Ode et al., 2011). In another study, umbilical cord-derived MSCs underwent cyclic uniaxial stretching for ten days. Here, the expression of CD73 was also significantly decreased as strain increased (Kang et al., 2011). CD73 is an ecto-5'-nucleotidase that is attached to the outer plasma membrane by a glycosyl phosphatidylinositol (GPI)-anchor. It catalyses the hydrolysis of the phosphoric ester bond of 5'-ribo- and deoxyribonucleotides to the corresponding ribo- and deoxyribonucleoside, and phosphate (Hunsucker et al., 2005; Sträter, 2006), e.g. it generates extracellular adenosine by the dephosphorylation of adenosine 5'-monophosphate. Although CD73 is one major cell surface marker defining MSCs according to The International Society for Cellular Therapy (ISCT), it is surprising that little is known about the function of CD73 in these cells (Dominici et al., 2006). Interestingly, CD73 expression is regulated by Wnt- $\beta$-catenin signalling, one of the major pathways in bone homeostasis (Spychala and Kitajewski, 2004). Moreover, CD73 is also regulated by cytokines and growth factors, such as TGF- $\beta$, IL- $1 \beta$ and TNF- $\alpha$, and hypoxia that are found in the haematoma during the early phase of bone healing (Hunsucker et al., 2005; Thompson et al., 2004), and recently, CD73 has 
been reported to be involved in osteogenic differentiation: Lack of CD73 causes a lower bone mineral content in the trabecular bone of male mice, accompanied with decreased osteocalcin serum levels and reduced expression of osteogenic mRNA-markers in calvarial and femoral bone. Primary calvarial osteoblasts of CD73-deficient mice produce less alkaline phosphatase (ALP) and calcified bone nodules. In contrast, CD73-over expressing MC3T3-E1 cells express more osteocalcin (Bglap) and bone sialoprotein 2 (Ibsp) and produce more ALP and calcified bone nodules (Takedachi et al., 2012). Little is known about the role of CD73 in chondrogenesis of MSCs, except that CD73 is down-regulated during differentiation (Delorme et al., 2008; Song et al., 2006). One possible mechanism by which CD73 mediates the effects on osteogenic MSC differentiation could be via adenosine receptor signalling. In MC3T3-E1 cells, the expression of adenosine A2A receptors (A2AAR) and $\mathrm{A} 2 \mathrm{~B}$ receptors (A2BAR) increased during culture in osteoblastic mineralisation. In addition, enhanced expression of osteocalcin and bone sialoprotein in CD73-over expressing MC3T3-E1 cells was suppressed by treatment with an A2BAR antagonist but not with an A2AAR antagonist (Takedachi et al., 2012). In contrast, treatment with an A2AAR antagonist reduced the number of procollagen alpha2 type I-positive murine BM-MSCs in cultures (Katebi et al., 2009). These findings indicate that $\mathrm{CD} 73$, adenosine and adenosine receptors may also play a critical role in promoting differentiation of MSCs. Therefore, we hypothesise that CD73 plays a fundamental role in MSC-mediated bone fracture healing and may provide a thus far underestimated, therapeutic target to guide this regenerative process.

In the present study, we aimed to analyse the differentiation capacity of mechanically loaded MSCs and the putative involvement of CD73 under conditions relevant for bone healing. In order to do so, we mimicked the early phase fracture gap conditions by embedding the MSCs in fibrin, the major extracellular matrix of the haematoma, and by stimulating the cells with cycliccompressive loading at a physiological amplitude and frequency.

\section{Materials and Methods}

\section{Cell isolation, culture and characterisation}

MSCs were isolated from bone marrow of 10-12 weeks old male Lewis rats and selected by plastic adherence (Dobson et al., 1999). Dulbecco's modified Eagle's medium (DMEM) (Gibco, Grand Island, NY, USA) supplemented with $10 \%$ foetal calf serum (FCS) (Biochrom AG, Berlin, Germany) and $10 \mathrm{U} / \mathrm{mL}$ penicillin plus $100 \mu \mathrm{g} / \mathrm{mL}$ streptomycin was used as expansion medium for MSCs. Only cells from passages 2-4 were used for experiments. The MSC-character was validated using flow cytometric analysis for MSC cell surface marker expression (positive: CD29, CD44, CD73, CD90, CD105, CD106 and CD166; negative: CD34, CD45, HLA-DR) and differentiation assays (Dominici et al., 2006).

Osteoblastic cells were isolated by the explant culture (Declercq et al., 2004). Briefly, skin, soft connective tissue, and periosteum were removed from tibiae and femora. Next, the diaphyses were cut free of epiphyseal cartilage. Bone was cut into pieces of approximately $2 \times 2 \mathrm{~mm}^{2}$ and washed by repeatedly vortexing in $20 \mathrm{~mL}$ phosphatebuffered saline (PBS) to remove blood and bone marrow. Approximately 20 bone pieces were incubated with culture medium in $175 \mathrm{~cm}^{2}$ tissue culture flasks for 2 weeks with medium exchange every 3-4 d.

\section{Bioreactor experiments}

The bioreactor system used has been described previously (Ode et al., 2011). Briefly, MSCs from passages 2-4 and osteoblasts (OBs) from passage 1 were trypsinised, and $2 \times 10^{6}$ cells in $350 \mu \mathrm{L}$ of bioreactor medium (culture medium containing $2.4 \%$ Trasylol (Bayer, Leverkusen, Germany)) were mixed with $300 \mu \mathrm{L}$ of fibrinogen/ bioreactor medium (1:2) mixture and $50 \mu \mathrm{L}$ of thrombin $\mathrm{S} /$ bioreactor medium (1:2) mixture (Tissucol; Baxter, Munich, Germany). This $700 \mu \mathrm{L}$ cells/fibrinogen/thrombin mixture was placed between two spongiosa bone chips and allowed to solidify for $30 \mathrm{~min}$ at $37^{\circ} \mathrm{C}$. The sandwich construct was placed into the bioreactor, and $25 \mathrm{~mL}$ of bioreactor medium was added. A strain of approximately $20 \%$ at a frequency of $1 \mathrm{~Hz}$ was applied in accordance with in vivo measurements of interfragmentary movement (Claes et al., 1998). Mechanical loading was carried out for $72 \mathrm{~h}$. Non-loaded cells were kept in a second bioreactor under equal experimental conditions without any mechanical load. Afterwards, both loaded and nonloaded cells within the fibrin construct were either isolated by $225 \mathrm{U}$ trypsin/1 mL PBS and further analysed by flow cytometry and differentiation assays or directly frozen in liquid nitrogen for RNA isolation. In order to reduce any bias through trypsin digestion in our experimental setting, each cell pair (loaded/non-loaded and MSCs/OBs) was treated in parallel under equal experimental conditions. Equal levels of cell viability and activity were validated by means of the electronic cell counter system CASY ${ }^{\circledR}$ DT (Schaerfe System, Reutlingen, Germany) and a CellTiter 96 AQueous test (MTS test; Promega, Mannheim, Germany), respectively.

\section{Flow cytometry}

For flow cytometry, cells within the fibrin construct were isolated by $225 \mathrm{U}$ trypsin/1 mL PBS and stained with the following antibodies: rabbit (anti-rat CD14), mouse (anti-rat CD34):FITC, rabbit (anti-rat CD105), and rabbit (anti-rat CD166) (Santa Cruz Biotechnology, Heidelberg, Germany), Armenian hamster (anti-rat CD29):FITC and mouse (anti-rat CD106) (Biolegend, San Diego, CA, USA), mouse (anti-rat CD45) and mouse (anti-rat CD90) (Acris Antibodies, Herford, Germany), mouse (anti-rat CD44) (AbD Serotec, Düsseldorf, Germany), mouse (anti-rat CD73) (BD Biosciences, Heidelberg, Germany), isotype Armenian hamster IgG:FITC (Biolegend, San Diego, CA, USA), rat (anti-mouse IgG):PE (BD Bioscience, Heidelberg, Germany) and donkey (anti-rabbit IgG):Cy5 (Dianova, Hamburg, Germany). Cells were analysed using FACSCalibur. 30,000 events were acquired and analysed using the FlowJo software. 
Table 1. Primers used for quantitative PCR.

\begin{tabular}{|c|c|c|c|}
\hline Protein & Gene & Primer Sequence (forward / reverse) & Reference \\
\hline \multicolumn{4}{|c|}{ Adenosine receptor } \\
\hline \multirow[t]{2}{*}{ Adenosine A1 receptor } & \multirow[t]{2}{*}{ Adoral } & 5' CCTTCTGCTTCATCGTGTCA 3' & \multirow{8}{*}{$\begin{array}{l}\text { (Jenner and Rose'Meyer, } \\
\text { 2006; Rose'Meyer et al., } \\
\text { 2003) }\end{array}$} \\
\hline & & 5' CTGGGTCACCACTGTCTTGT 3' & \\
\hline \multirow[t]{2}{*}{ Adenosine A2a receptor } & \multirow[t]{2}{*}{ Adora $2 a$} & 5' CCT CTT CTT CGC CTG TTT TG 3' & \\
\hline & & 5' GTT CCC GTC TTT CTG ACT GC 3' & \\
\hline \multirow[t]{2}{*}{ Adenosine $\mathrm{A} 2 \mathrm{~b}$ receptor } & \multirow[t]{2}{*}{ Adora $2 b$} & 5' GCTCCATCTTTAGCCTCTTG 3' & \\
\hline & & 5' AACCCAGGAAAGGAGTCAG 3' & \\
\hline \multirow[t]{2}{*}{ Adenosine $\mathrm{A} 3$ receptor } & \multirow[t]{2}{*}{ Adora3 } & 5' GGTCCACTGGCCCATACACA 3' & \\
\hline & & 5' TGTAGGTGATTTGCAACCACA 3' & \\
\hline \multicolumn{4}{|c|}{ Cell surface marker } \\
\hline \multirow[t]{2}{*}{ ecto-5'-nucleotidase (CD73) } & \multirow[t]{2}{*}{$N t 5 e$} & 5' GCAAGGAAGAACCCAACGTA 3' & \\
\hline & & 5' TCAGTCCTTCCACACCGTTA 3' & \\
\hline \multicolumn{4}{|c|}{ Chondrogenic marker } \\
\hline \multirow[t]{2}{*}{ aggrecan } & \multirow[t]{2}{*}{ Acan } & 5' CCACTG GAGAGGACTGCGTAG 3' & \multirow[t]{4}{*}{ (Peng et al., 2008) } \\
\hline & & 5' GGTCTGTGCAAGTGATTCGAG 3' & \\
\hline \multirow[t]{2}{*}{ collagen type 2 alpha 1} & \multirow[t]{2}{*}{ Col2al } & 5' GACCCTCTCTTAGCCACACACAC 3' & \\
\hline & & 5' AAGCTGCCCAGAATCCTAAATCT 3' & \\
\hline \multirow[t]{2}{*}{ fibromodulin } & \multirow[t]{2}{*}{ Fmod } & 5' ACGTCTACACCGTCCCTGACA 3' & \multirow[t]{4}{*}{ (Peng et al., 2008) } \\
\hline & & 5' CCTGCAGCTTGGAGAAGTTCA 3' & \\
\hline \multirow[t]{2}{*}{ Sry-box containing gene 9} & \multirow[t]{2}{*}{$\operatorname{Sox} 9$} & $5^{\prime}$ TCCTAACGCCATCTTCAAGG 3' & \\
\hline & & 5' CCCCTCTCGTTTCAGATCAA 3' & \\
\hline \multicolumn{4}{|c|}{ Osteogenic marker } \\
\hline \multirow[t]{2}{*}{ alkaline phosphatase } & $A l p l$ & 5' CCTTGAAAAATGCCCTGAAA 3' & \\
\hline & & 5' CTTGGAGAGAGCCACAAAGG 3' & \\
\hline osteocalcin & Bglap & 5' TGAGGACCCTCTCTCTGCTC 3' & \\
\hline & & 5' AGGTAGCGCCGGAGTCTATT 3' & \\
\hline collagen type 1 alpha 1 & Collal & 5' GGAGAGAGTGCCAACTCCAG 3' & (Peng et al., 2008) \\
\hline & & 5' CCACCCCAGGGATAAAAACT3' & \\
\hline bone sialoprotein 2 & $I b s p$ & 5' TCTGCATTTTGGGGATGG 3' & \\
\hline & & 5' CCGTTTCAGAGGAGGATAAAAG 3' & \\
\hline runt-related transcription factor & Runx2 & 5' GCCGGGAATGATGAGAACTA 3' & \\
\hline 2 & & 5' GGACCGTCCACTGTCACTTT 3' & \\
\hline osteopontin & Sppl & 5' GAGGAGAAGGCGCATTACAG 3' & \\
\hline & & 5' ATGGCTTTCATTGGAGTTGC 3' & \\
\hline & & Housekeeping gene & \\
\hline$\beta$-actin & $A c t b$ & 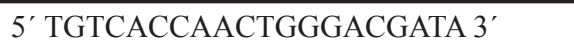 & \\
\hline & & 5' GGGGTGTTGAAGGTCTCAAA 3' & \\
\hline glyceraldehyde-3-phosphate & Gapdh & 5' ATGGGAAGCTGGTCATCAAC 3' & \\
\hline dehydrogenase & & 5' GTGGTTCACACCCATCACAA 3' & \\
\hline elongation factor 1 -alpha 1 & Eefla & 5' CCCTGTGGAAGTTTGAGACC 3' & \\
\hline & & 5' CTGCCCGTTCTTGGAGATAC 3' & \\
\hline
\end{tabular}



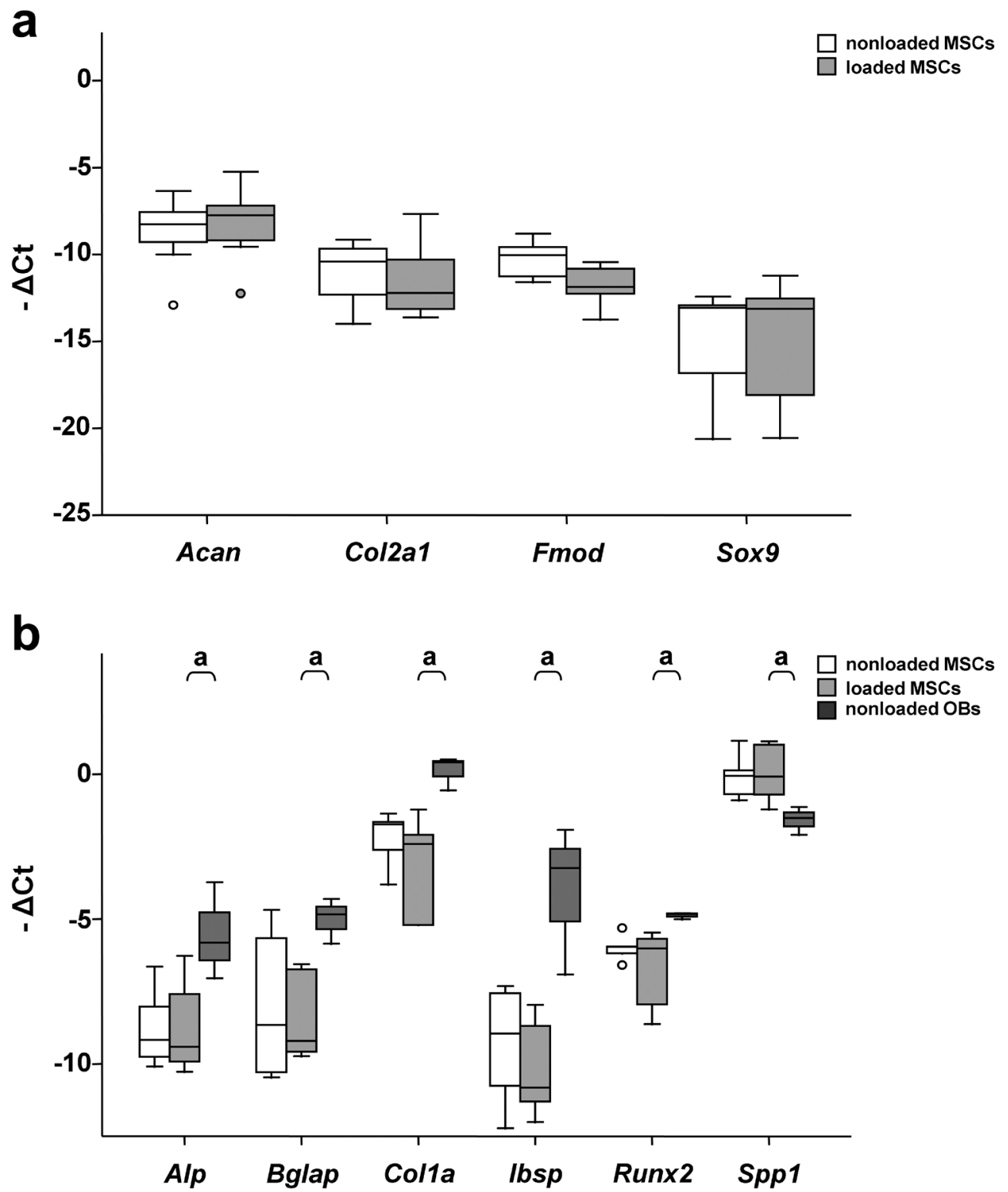

Fig. 1. MSCs neither increase their chondrogenic differentiation marker expression nor obtain an osteogenic phenotype by the sole stimulus of cyclic compression. The expression of mRNA specific for (A) chondrogenic, and (B) osteogenic differentiation markers of loaded MSCs, non-loaded MSCs and non-loaded osteoblasts (OBs) were evaluated by quantitative qRT-PCR and normalised for the housekeeping genes Actb, Gapdh, and Eefla. (MSCs: $n=6$; OBs: $n=3$; ${ }^{\circ}$, outlier; a, $p<0.05$ ).

RNA isolation, cDNA synthesis, and quantitative reverse transcription-polymerase chain reaction Total RNA from frozen cell-fibrin constructs was extracted using Trizol ${ }^{\circledR}$ Reagent (Invitrogen, Karlsruhe, Germany) and reverse transcribed to cDNA using iScript ${ }^{\mathrm{TM}} \mathrm{cDNA}$ Synthesis kit (Bio-Rad, Munich, Germany), according to the manufacturer's instructions. RNA quality was evaluated by visualising the $18 \mathrm{~S} / 28 \mathrm{~S}$ rRNA on a $1.5 \%$ agarose gel. Quantification of the differentiation markers were assessed by quantitative reverse transcription-polymerase chain reaction (qRT-PCR) using the iQTM SYBR ${ }^{\circledR}$ Green Supermix and the iQTM 5 Multicolor Real-time PCR Detection System and software (Bio-Rad, Munich, Germany) using the delta-delta-Ct-method. The transcript expression was normalised versus the housekeeping gene $\beta$-actin $(A c t b)$, elongation factor 1-alpha 1 (Eefla), and glyceraldehyde-3-phosphate dehydrogenase (GAPDH). The primers used in the real-time PCR assay were commercially purchased (Invitrogen, Karlsuhe, Germany; Table 1). Amplification efficiency (E) was assessed to be between 1.8 and 2. Transcripts from five MSC donors were analysed. Each experiment was conducted in triplicate.

\section{MSC differentiation}

To induce osteogenic differentiation, $1.92 \times 10^{4} \mathrm{MSCs}$ were cultured on 24-well plates and exposed to osteogenic differentiation media $(200 \mu \mathrm{M}$ ascorbic acid, $7 \mathrm{mM}$ B-glycerol phosphate, $0.01 \mu \mathrm{M}$ dexamethasone; $21 \mathrm{~d}$ ). 
Fig. 2. Osteoblasts express more CD73 than MSCs. The expression of MSC cell surface markers of loaded and non-loaded MSCs, and non-loaded osteoblasts (OBs) was investigated by flow cytometry. Shown is the mean fluorescence intensity (MFI) of cells stained with specific antibodies after normalisation to isotype negative controls. (MSCs: $n=5$; OBs: $n=4{ }^{\circ}$, outlier; *, extreme value; a, $p<0.05$ ).
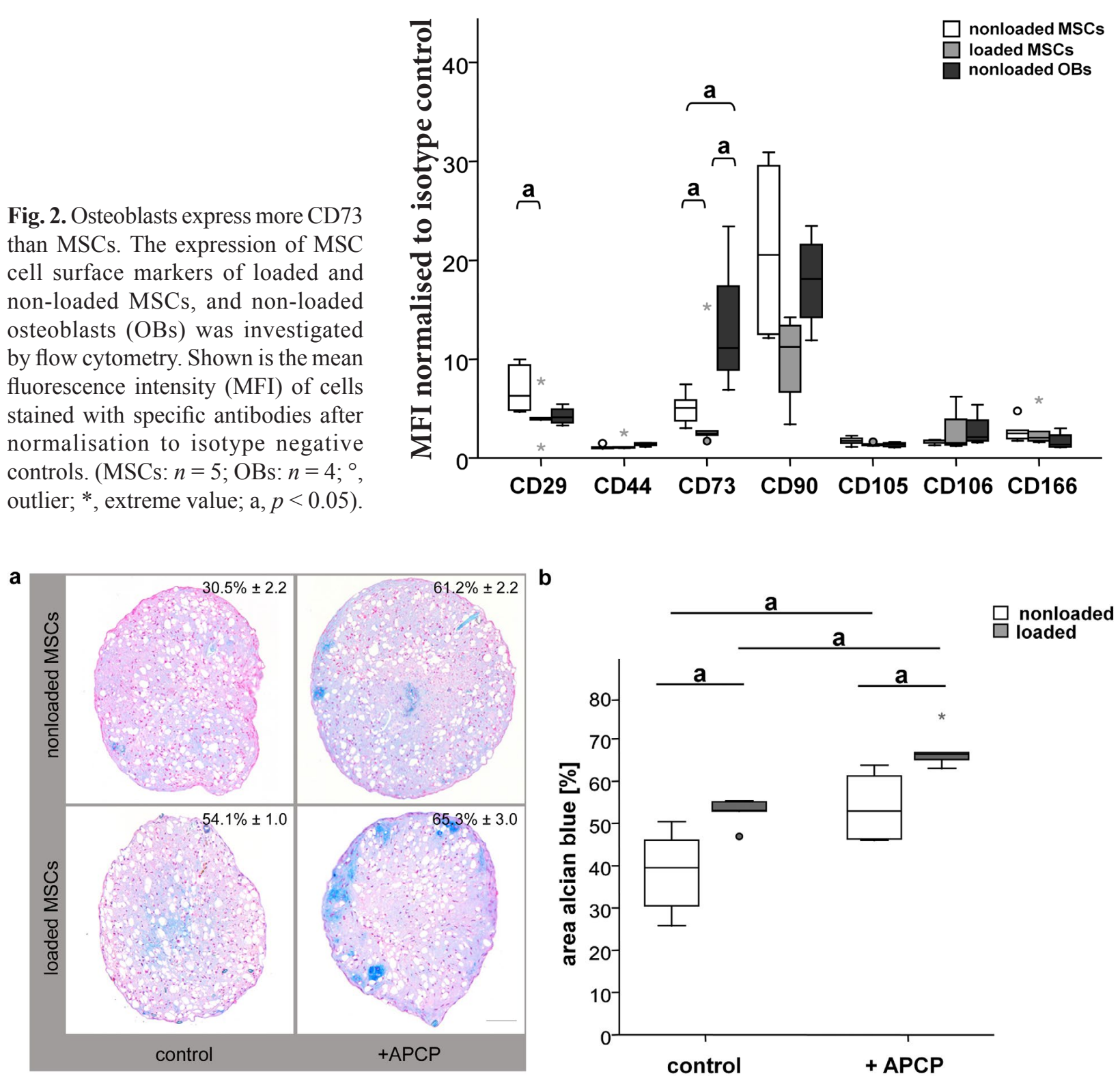

Fig. 3. Blocking of CD73 leads to increased chondrogenic differentiation of MSCs. MSCs were cultivated as pellet cultures in chondrogenic differentiation media supplemented with $120 \mu \mathrm{M}$ APCP. After $28 \mathrm{~d}$, matrix production of differentiated cells was detected with alcian blue. Chondrogenic matrix is stained in blue, cell nuclei in red. (A) Shown are representative stained pellet sections of differentiated non-loaded (top) and loaded MSCs (bottom) of one animal with the mean value of the alcian blue positive stained area \pm SD. Bar indicates $100 \mu \mathrm{m}$. (B) The alcian blue positive stained area was quantified using the AxioVision software package 4.7 and normalised to total area. At least three different sections of one pellet were analysed. Abbreviation: APCP, CD73 inhibitor adenosine 5'-( $\alpha$, $\beta$-methylene)diphosphate; $\left(n=5\right.$; $^{\circ}$, outlier; *, extreme value; a, $\left.p<0.05\right)$.

Osteogenic differentiation was detected by alizarin red (AR) staining. AR positively stained matrix was quantified after dissolving AR in cetylpyridinium chloride and then normalised to cell number, as determined using MTStest (CellTiter 96 Aquaeous, Promega, Madison, WI, USA), according to the manufacturer's instructions. Each experiment was conducted in triplicate. ALP activity was measured at day 7,11 and 14 according to a protocol described elsewhere (Krause et al., 2011). Briefly, all buffers and substrate were preheated to $37^{\circ} \mathrm{C}$. Cells were washed using $400 \mu \mathrm{L}$ PBS and $500 \mu \mathrm{LAP}-B u f f e r(100 \mathrm{mM}$
$\mathrm{NaCl}, 100 \mathrm{mM}$ Tris, $1 \mathrm{mM} \mathrm{MgCl}$; pH 9.0). $250 \mu \mathrm{L}$ APBuffer and an equal volume of p-nitrophenyl phosphate (pNPP, Sigma Aldrich, Munich, Germany) solution (1 mg/ $\mathrm{mL}, 1 \mathrm{M}$ diethanolamine (DEA), $\mathrm{pH}$ 9.8) were added. Cells were incubated for $5 \mathrm{~min}$ at $37^{\circ} \mathrm{C}$ and reaction was stopped using $500 \mu \mathrm{L} 1 \mathrm{M} \mathrm{NaOH}$. Duplicates of $100 \mu \mathrm{L}$ were transferred to a 96-well plate and absorption was measured at $405 \mathrm{~nm}$ at a plate reader. After blank value subtraction, pNPP consumption, i.e. 4-nitrophenolate accumulation, was calculated using a molar extinction coefficient of $18450 \mathrm{~L} \mathrm{x} \mathrm{mol}^{-1} \mathrm{x} \mathrm{cm}^{-1}$. ALP activity was 
a

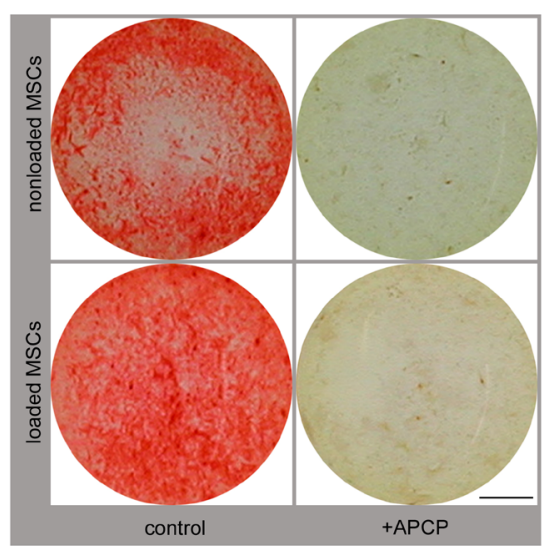

C

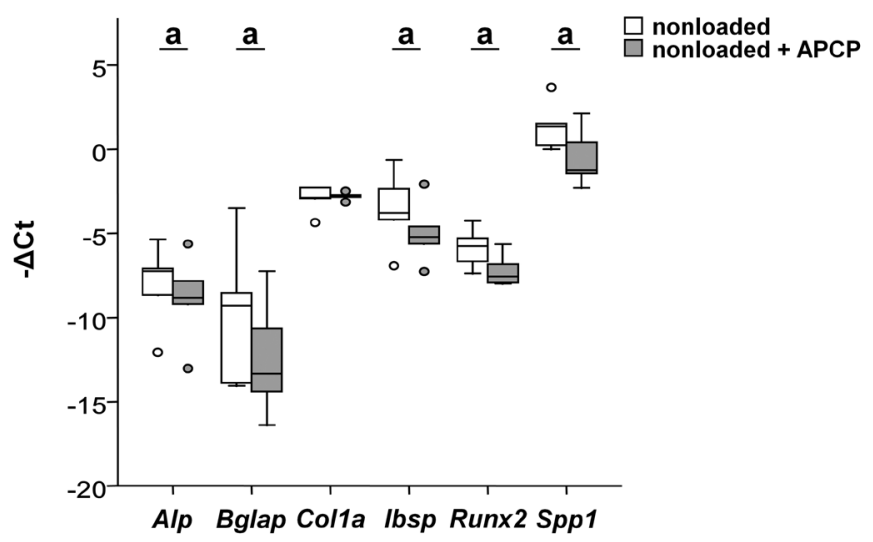

b

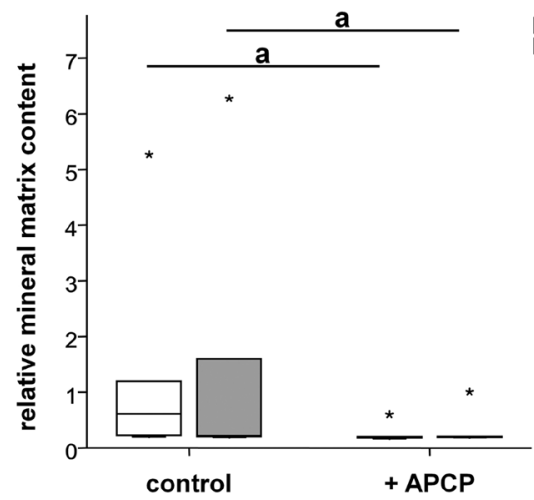

d

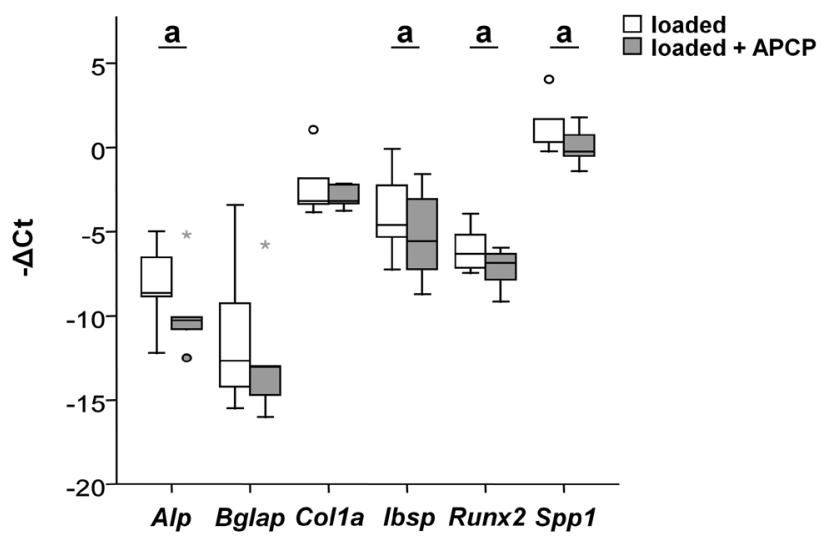

Fig. 4. Blocking of CD73 leads to decreased osteogenic differentiation of MSCs. MSCs were cultivated in osteogenic differentiation media supplemented with $120 \mu \mathrm{M} \mathrm{APCP}$. (A) Shown are representative pictures of non-loaded (top) and loaded MSCs (bottom) of one animal. Bar indicates $3 \mathrm{~mm}$. (B) Osteogenic differentiation was detected by alizarin red (AR) staining. AR positive stained matrix was quantified after dissolving of AR in cetylpyridinium chloride and then normalised to cell number, as determined using MTS-test. (C and D) The expression of mRNA specific for osteogenic differentiation markers of (C) loaded and (D) nonloaded MSCs was evaluated by quantitative qRT-PCR and normalised for the housekeeping genes Actb, Gapdh, and Eefla. Abbreviation: APCP, CD73 inhibitor adenosine 5 '- $\left(\alpha, \beta\right.$-methylene)diphosphate; $\left(n=5\right.$; $^{\circ}$, outlier; *, extreme value; a, $\left.p<0.05\right)$.

defined as nmol 4-nitrophenolate accumulation in $1 \mathrm{~min}$ at $37{ }^{\circ} \mathrm{C}$. Values were normalised to cell number using Resazurin solution (Alamar Blue, Life Technologies, Darmstadt, Germany), according to the manufacturer's instructions. Each experiment was conducted in triplicate. For chondrogenic differentiation, a pellet culture in chondrogenic differentiation media (10 ng/mL TGF- $\beta 1$, $10^{-7} \mathrm{M}$ dexamethasone, $50 \mu \mathrm{g} / \mathrm{mL}$ ascorbic acid, $40 \mu \mathrm{g} /$ $\mathrm{mL}$ proline, $100 \mu \mathrm{g} / \mathrm{mL}$ pyruvate, $6.25 \mu \mathrm{g} / \mathrm{mL}$ insulintransferrin-sodium selenite media supplement (ITS), $1.25 \mathrm{mg} / \mathrm{mL}$ bovine serum albumin (BSA), $5.35 \mathrm{mg} / \mathrm{mL}$ linoleic acid) as described was used for $28 \mathrm{~d}$ (Sekiya et al., 2002). Chondrogenic differentiation was detected by Alcian blue staining. A CD73 inhibitor, adenosine 5' $-(\alpha$, $\beta$-methylene)diphosphate (APCP; $120 \mu \mathrm{M}$ ) was employed in differentiation assays. The alcian blue positive stained area was quantified using the AxioVision software package 4.7 and normalised to total area. At least three different sections of one pellet were analysed.

\section{Statistics}

The SPSS 17.0 software package (SPSS, Inc., Chicago, IL, USA) was used for statistical evaluation. If not stated otherwise, results from at least five independent experiments (i.e. non-pooled MSCs or OBs from at least five different animals) were analysed for statistical significance either using Wilcoxon Test (related samples) or Mann-Whitney $\mathrm{U}$ Test (independent samples). Loaded/nonloaded and APCP-treated/non-treated control cells (MSCs and OBs) were always analysed pairwise originating from the same animal and under equal experimental conditions. MSCs and osteoblasts were non-related and therefore treated as independent samples in comparative analyses. Results are presented as median $\pm \mathrm{min} / \mathrm{max}$. A significance level was set at $p<0.05$. 


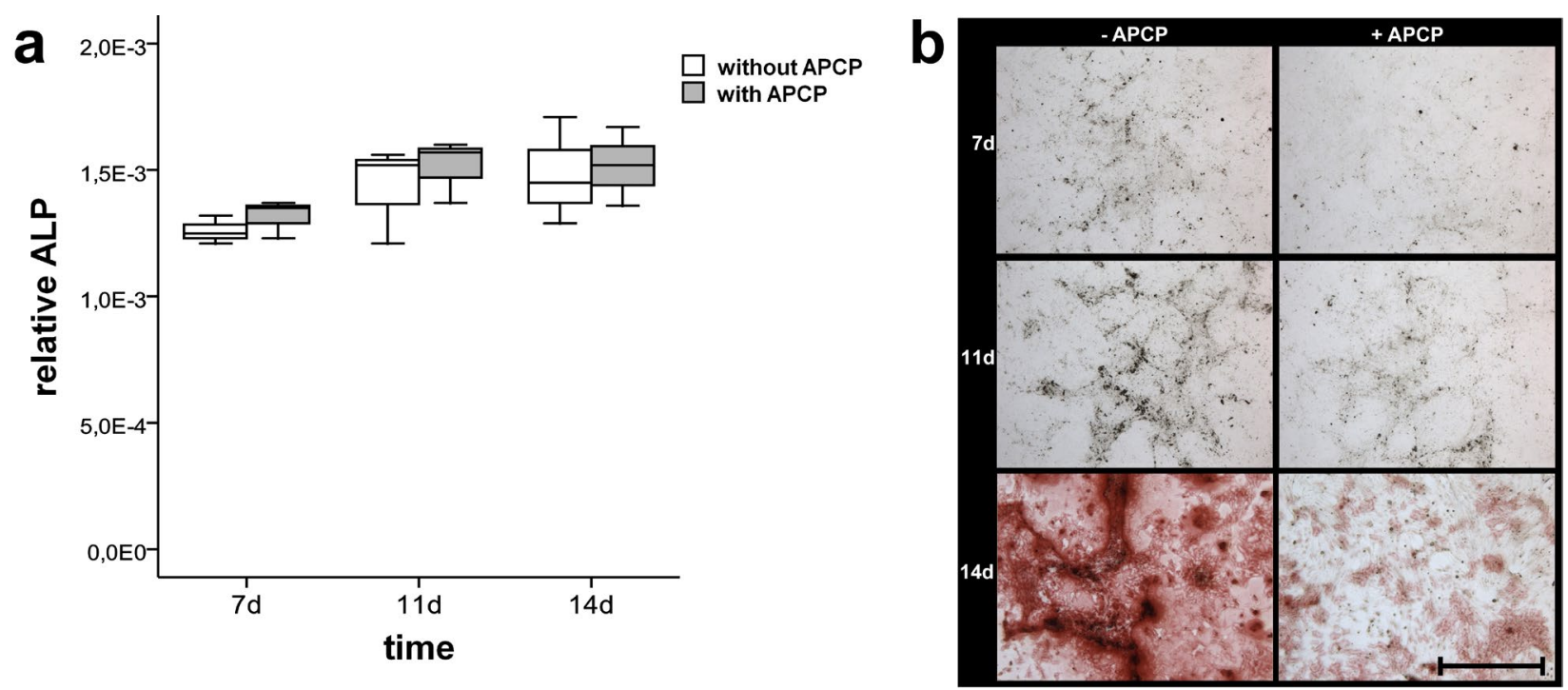

Fig. 5. Enzyme activity of ALP is not affected by blocking of CD73. MSCs were cultivated in osteogenic differentiation media supplemented with $120 \mu \mathrm{M}$ APCP. (A) After 7, 11 and $14 \mathrm{~d}$ ALP activity, i.e. 4-nitrophenolate accumulation, was measured and normalised to cell number. (B) Shown are representative pictures of APCP-treated (right) and nontreated MSCs (left) of one animal after AR staining. Bar indicates $1000 \mu \mathrm{m}$. Abbreviations: APCP, CD73 inhibitor adenosine 5'-( $\alpha, \beta$-methylene $)$ diphosphate; $\mathrm{AR}$, alizarin red $(n=3)$.

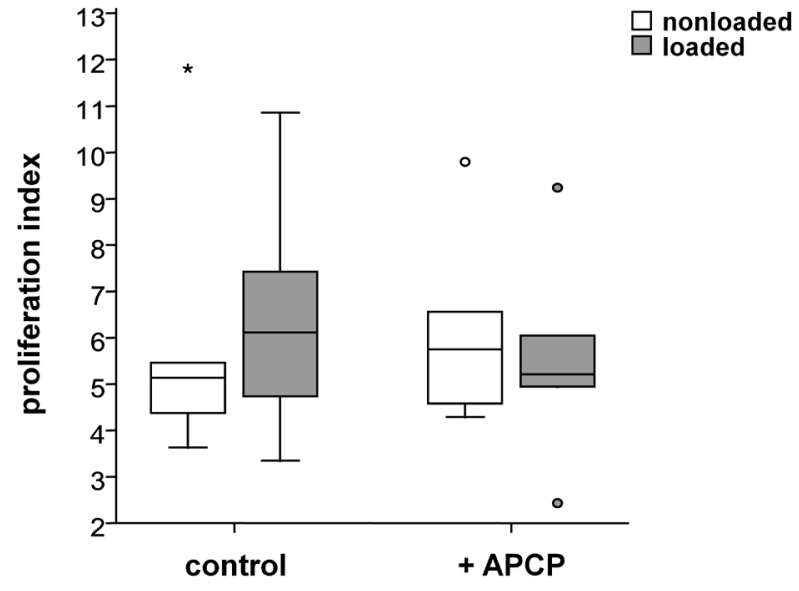

Fig. 6. APCP does not affect MSC proliferation. Proliferation of loaded and non-loaded MSCs was determined by measuring cell activity on day 1 and 6 by MTS-test. The proliferation index was calculated by normalising the day 1 to the day 6 values. Abbreviations: APCP, adenosine 5' -( $\alpha, \beta$-methylene)diphosphate; w/o, without $\left(n=5 ;{ }^{\circ}\right.$, outlier; $*$, extreme value).

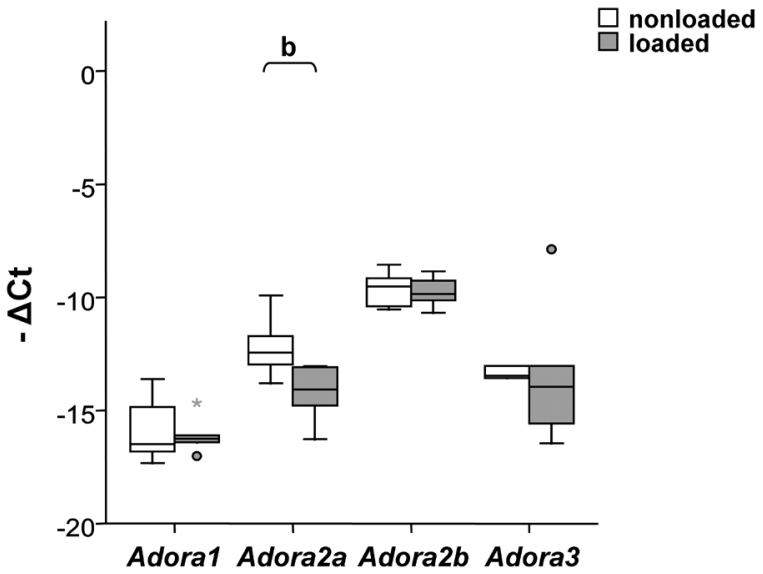

Fig. 7. Adenosine receptor Adora2a is down-regulated in MSCs after mechanical loading. The expression of mRNA specific for the four adenosine receptors of loaded and non-loaded MSCs was evaluated by qRTPCR and normalised for the housekeeping genes Actb, Gapdh, and Eefla. $\left(n=6\right.$; ${ }^{\circ}$, outlier; *, extreme value; b, $p=0.075)$.

\section{Results}

In accordance with previously published data, our first aim was to clarify whether mechanical stimulation alone leads to changes of MSCs differentiation marker expression, which was investigated by quantitative RTPCR analysis directly after cyclic-compression. Among the chondrogenic (Acan, Col2a1, Fmod, Sox9) and osteogenic markers (Alpl, Bglap, Colla1, Ibsp, Runx2, Spp1), none was significantly regulated (Fig. 1). To further control their stage of differentiation, loaded and non-loaded
MSCs were compared to non-loaded osteoblasts with regard to their osteogenic differentiation markers. Gene expression analysis revealed that Alpl, Bglap, Collal, Ibsp, and, Runx 2 were significantly more highly expressed in non-loaded osteoblasts compared to MSCs. In contrast, the Sppl level was significantly lowered after loading. In addition, flow cytometry analysis of cell surface markers revealed that CD73 expression was significantly increased in non-loaded osteoblasts compared to loaded and non-loaded MSCs (Fig. 2). In line with these results, CD73 expression is also increased in MSCs during their 
osteogenic differentiation (relative gene expression: $2^{-\Delta \Delta C t}$ $(\mathrm{CD} 73)=2.69, n=3$, Student's $t$-test, $p=0.002)$. CD29 and CD73 were down-regulated in MSCs in response to loading and these observations remained persistent over a period of additional $6 \mathrm{~d}$, where MSCs were kept non-loaded after $3 \mathrm{~d}$ of cyclic-compression, as described previously (Ode et al., 2011).

Subsequently, the putative involvement of CD73 in chondrogenic and osteogenic differentiation in MSCs was investigated. Mechanical stimulation and supplementation of chondrogenic media with APCP stimulated chondrogenic differentiation of MSCs (Fig. 3). However, the overall chondrogenic response of rat MSCs is less strong compared with human MSCs under almost identical conditions, which could not be improved by the additional treatment with BMP-2 in the differentiation media (data not shown).

Supplementation of osteogenic media with APCP inhibited osteogenic differentiation of loaded and nonloaded MSCs. In addition, osteogenic differentiation marker expression (Alpl, Bglap, Colla1, Ibsp, Runx2, $S p p 1)$ was significantly reduced in APCP-treated loaded and non-loaded MSCs (Fig. 4). As ALP is a key regulator of osteogenesis, ALP activity of MSCs was analysed under the direct influence of APCP and found to be unaffected (Fig. 5). Cell viability was also unaffected by APCP (Fig. $6)$.

One major signal transduction pathway, which is activated via CD73 mediated adenosine, is the adenosine receptor pathway, possibly being involved in regulating MSC differentiation. Thus, the adenosine receptor expression pattern was investigated. MSCs expressed the four known adenosine receptors (Adora1, Adora2a, Adora2b, Adora3) at the mRNA level. After mechanical stimulation of MSCs, Adora2a was down-regulated by a mean factor of 0.37 (Fig. 7).

\section{Discussion}

The stem cell character of MSCs depends not only on the expression of specific cell surface markers, but also on the ability to differentiate into the osteogenic, chondrogenic, and adipogenic lineage. Therefore, the differentiation potential of MSCs after mechanical loading was investigated. In this study, loading conditions similar to the early phase of fracture healing resulted in enhanced chondrogenic differentiation potential of MSCs. Hence, the response of MSCs to mechanical loading followed current models that suggest that compressive load supports chondrogenic MSC differentiation (Table 2) (Campbell et al., 2006; Mauck et al., 2007; Pelaez et al., 2009). In contrast, osteogenic differentiation of MSCs was unaffected by cyclic compression (3D) adding weight to the notion that osteogenic differentiation requires a different mechanical stimulus, such as cyclic equibiaxial/uniaxial strain (2D) or four-point bending (Table 2) (David et al., 2007; Jagodzinski et al., 2004; Koike et al., 2005; Mauney et al., 2004). Little is known about the function of CD73 in MSCs thus far. Previously, CD73 was shown to be downregulated in response to mechanical loading (Kang et al.,
2011; Ode et al., 2011). Therefore, the putative involvement of CD73 in the enhanced chondrogenic differentiation of loaded MSCs was investigated. Here, through CD73 antagonist treatment, MSC chondrogenic differentiation was increased similar to the effect observed after loading. Chondrogenesis of MSCs is typically induced when the cells are exposed to TGF- $\beta$ and hypoxia (Chamberlain et al., 2007). Both parameters also influence the expression and activity of CD73: TGF- $\beta$ induces CD73 expression on activated CD4+ and CD8+ T-cells, dendritic cells and macrophages (Regateiro et al., 2011); and, hypoxia is a major inducer of CD73 expression, e.g. in intestinal epithelia, which is likely due to a hypoxia inducible factor-1 $\alpha(\mathrm{HIF}-1 \alpha)$ responsive element in its promoter region (Hunsucker et al., 2005; Thompson et al., 2004). These data might suggest that a higher CD73 expression correlates with an increased chondrogenesis. However, it is well known that CD73 expression is regulated by a number of cytokines in a cell-type specific manner: for example, interferon (INF)- $\alpha$ and $-\gamma$ up-regulate CD73 levels in human endothelial cells, but not in lymphocytes and monocytes (Hunsucker et al., 2005; Niemela et al., 2004). TNF- $\alpha$ and IL- $1 \beta$ induce CD73 expression and activity in blood mononuclear cells and rat glomerular mesangial cells (Hunsucker et al., 2005), whereas TNF- $\alpha$ decreases it in human endothelial cells (Kalsi et al., 2002). Thus, it may well be that in MSCs either CD73 is down-regulated by hypoxia and/or TGF- $\beta$ or the regulation of this enzyme is even more complex. This hypothesis is supported by the fact that CD73 is down-regulated during chondrogenic differentiation of MSCs (Delorme et al., 2008; Song et al., 2006). Therefore, further research is needed to shed light on the influence of cytokines on CD73 expression in MSCs and other cell types present in the fracture haematoma in vivo.

Interestingly, CD73 also seems to be important in the osteogenic differentiation of MSCs. In our study, through CD73 antagonist treatment, the mineral matrix deposition of MSCs was almost completely abolished and osteogenic differentiation marker expression, such as Bglap and Ibsp, decreased. Thus, these results complement the findings for osteoblasts from CD73-deficient mice (Takedachi et al., 2012). Moreover, osteoblasts express more CD73 on their cell surface than their undifferentiated progenitor.

One possible mechanism by which CD73 mediates the effects on MSC differentiation could be via adenosine receptor signalling. CD73 dephosphorylates AMP to generate extracellular phosphate and adenosine, which can be further processed by adenosine receptors. Adenosine receptors contain seven transmembrane domains and couple to intracellular $\mathrm{G}$ proteins. They are divided into four subtypes - the adenosine A1, A2a, A2b and A3 receptor $(\mathrm{R})$ - which vary in their affinities for adenosine (Resta and Thompson, 1997). In this study, the four adenosine receptors were expressed on MSCs as described previously (Katebi et al., 2009). Following mechanical stimulation, A2aR tends to be down-regulated. These data are in line with other studies that reported that CD73 and $\mathrm{A} 2 \mathrm{aR}$ expression are mutually regulatory, i.e. A2aR expression increases CD73 expression and vice versa in murine MSCs and human B-cells (Katebi et al., 2009; 
Table 2. Mechanobiological responses of MSCs.

\begin{tabular}{|c|c|c|c|c|c|c|}
\hline \multirow{2}{*}{$\begin{array}{l}\begin{array}{l}\text { Cell type } \\
\text { (Species) }\end{array} \\
\text { BM-MSC } \\
\text { (Rabbit) }\end{array}$} & \multicolumn{2}{|l|}{ Loading conditions } & \multirow{2}{*}{$\begin{array}{l}\text { Matrix } \\
\text { Agarose }\end{array}$} & \multicolumn{2}{|l|}{ Cell response } & \multirow{2}{*}{$\begin{array}{l}\text { Reference } \\
\text { (Huang et al., 2004) } \\
\text { (Huang et al., 2005) }\end{array}$} \\
\hline & $\begin{array}{l}\text { Cyclic compression* } \\
10 \%, 1 \mathrm{~Hz}, \\
4 \mathrm{~h} / \mathrm{d} \text { over } 2 \mathrm{~d}, 3 \mathrm{~d}, 7 \mathrm{~d}, \\
14 \mathrm{~d}\end{array}$ & $3 \mathrm{D}$ & & $\begin{array}{l}\text { Increase in } \\
\text { aggrecan, collagen type II, c-Jun, Sox9, } \\
\text { TGF- } \beta \text { receptor mRNA } \\
\text { Decrease in } \\
\text { collagen type I mRNA }\end{array}$ & $\mathrm{C} \uparrow$ & \\
\hline $\begin{array}{l}\text { BM-MSC } \\
\text { (Human) }\end{array}$ & $\begin{array}{l}\text { Cyclic compression* } \\
10 \%, 1 \mathrm{~Hz}, \\
4 \mathrm{~h} / \mathrm{d} \text { over } 3 \mathrm{~d}\end{array}$ & $3 \mathrm{D}$ & Fibrin & $\begin{array}{l}\text { Increase in } \\
\text { aggrecan, collagen type II mRNA }\end{array}$ & $\mathrm{C} \uparrow$ & (Pelaez et al., 2009) \\
\hline $\begin{array}{l}\text { AT-MSC } \\
\text { (Goat) }\end{array}$ & $\begin{array}{l}\text { Pulsating fluid flow } \\
0.6 \mathrm{~Pa}, 5 \mathrm{~Hz}, 1 \mathrm{~h}\end{array}$ & $2 \mathrm{D}$ & Polylysine & $\begin{array}{l}\text { Decrease in } \\
\text { Alpl mRNA }\end{array}$ & $\mathrm{O} \downarrow$ & (Knippenberg et al., 2006) \\
\hline $\begin{array}{l}\text { BM-MSC } \\
\text { (Mouse } \\
\text { ST2 cell } \\
\text { line) }\end{array}$ & $\begin{array}{l}\text { Cyclic equibiaxial strain } \\
10-15 \%, 1 \mathrm{~Hz}, 2 \mathrm{~d}\end{array}$ & $2 \mathrm{D}$ & $\begin{array}{l}\text { Collagen } \\
\text { type I }\end{array}$ & $\begin{array}{l}\text { Increase in } \\
\text { proliferation; collagen type I mRNA } \\
\text { Decrease in } \\
\text { AP activity; } \\
\text { Runx2, osteocalcin mRNA }\end{array}$ & $\begin{array}{l}\mathrm{O} \uparrow \\
\mathrm{P} \uparrow\end{array}$ & (Koike et al., 2005) \\
\hline $\begin{array}{l}\text { BM-MSC } \\
\text { (Human) }\end{array}$ & $\begin{array}{l}\text { 4-point bending } \\
3 \%, 0.2 \mathrm{~Hz}, 20 \mathrm{~min}\end{array}$ & $3 \mathrm{D}$ & DMB & $\begin{array}{l}\text { Increase in } \\
\text { AP activity and ALPL mRNA }\end{array}$ & $\mathrm{O} \uparrow$ & (Mauney et al., 2004) \\
\hline $\begin{array}{l}\text { BM-MSC } \\
\text { (Rat) }\end{array}$ & $\begin{array}{l}\text { Cyclic equibiaxial strain } \\
0.3 \%, 0.5 \mathrm{~Hz}, 30 \mathrm{~min}, \\
5 \mathrm{~d} \text { static culture }\end{array}$ & $2 \mathrm{D}$ & Silicone & $\begin{array}{l}\text { Increase in } \\
\text { AP activity; DNA content; osteocalcin } \\
\text { protein }\end{array}$ & $\begin{array}{l}\mathrm{O} \uparrow \\
\mathrm{P} \uparrow\end{array}$ & (Yoshikawa et al., 1997) \\
\hline $\begin{array}{l}\text { BM-MSC } \\
\text { (Human) }\end{array}$ & $\begin{array}{l}\text { Cyclic uniaxial strain } \\
8 \%, 1 \mathrm{~Hz}, 3 \times 2 \mathrm{~h} / \mathrm{d} \\
\text { over } 4 \mathrm{~d}\end{array}$ & $2 \mathrm{D}$ & Silicone & $\begin{array}{l}\text { Increase in } \\
\text { Runx2, Alpl, collagen type I and III, } \\
\text { osteocalcin mRNA }\end{array}$ & $\mathrm{O} \uparrow$ & (Jagodzinski et al., 2004) \\
\hline $\begin{array}{l}\text { BM-MSC } \\
\text { (Bovine) }\end{array}$ & $\begin{array}{l}\text { Cyclic compression* } \\
10 \%, 1 \mathrm{~Hz}, 3 \mathrm{~h} / \mathrm{d} \\
\text { over } 5 \mathrm{~d}\end{array}$ & $3 \mathrm{D}$ & Agarose & $\begin{array}{l}\text { Increase in } \\
\text { proteoglycan deposition }\end{array}$ & $\mathrm{C} \uparrow$ & (Mauck et al., 2007) \\
\hline $\begin{array}{l}\text { BM-MSC } \\
\text { (Human) }\end{array}$ & $\begin{array}{l}\text { Cyclic compression* } \\
15 \%, 1 \mathrm{~Hz}, 1.5 \mathrm{~h} / \mathrm{d} \text { over } \\
8 \mathrm{~d}\end{array}$ & $3 \mathrm{D}$ & Alginate & $\begin{array}{l}\text { Increase in } \\
\text { collagen X mRNA }\end{array}$ & $\mathrm{C} \uparrow$ & (Campbell et al., 2006) \\
\hline $\begin{array}{l}\text { ST-MSC } \\
\text { (Bovine) }\end{array}$ & $\begin{array}{l}\text { Cyclic equibiaxial strain } \\
0.4 \%, 1 \mathrm{~Hz}, 300 \text { cycles/d }\end{array}$ & $2 \mathrm{D}$ & $\begin{array}{l}\text { Collagen } \\
\text { type I }\end{array}$ & $\begin{array}{l}\text { Increase in } \\
\text { AP positive cells; Runx2 and osteocal- } \\
\text { cin protein; Runx2, osteocalcin, and } \\
\text { osterix mRNA } \\
\text { Decrease in } \\
\text { Oil-red-O positive cells; Ppary protein; } \\
\text { Fabp4 and Ppar } \gamma \text { mRNA }\end{array}$ & $\begin{array}{l}\mathrm{O} \uparrow \\
\mathrm{A} \downarrow\end{array}$ & (David et al., 2007) \\
\hline $\begin{array}{l}\text { BM-MSC } \\
\text { (Rabbit) }\end{array}$ & $\begin{array}{l}\text { Cyclic compression* } \\
5 \%, 0.1 \mathrm{~Hz}, 10 \mathrm{~d}\end{array}$ & $3 \mathrm{D}$ & $\begin{array}{l}\text { PLCL, } \\
\text { fibrin }\end{array}$ & $\begin{array}{l}\text { Increase in } \\
\text { aggrecan, collagen type II protein and } \\
\text { mRNA; GAG content }\end{array}$ & $\mathrm{C} \uparrow$ & (Jung et al., 2009) \\
\hline $\begin{array}{l}\text { BM-MSC } \\
\text { (Rat) }\end{array}$ & $\begin{array}{l}\text { 4-point bending } \\
0.2 \%, 0.5 \mathrm{~Hz}, 40 \mathrm{~min}, \\
6 \mathrm{~h} \text { static culture }\end{array}$ & $2 \mathrm{D}$ & Silicone & $\begin{array}{l}\text { Increase in } \\
\text { Runx2, Alpl mRNA; AP protein; } \\
\text { cell number }\end{array}$ & $\begin{array}{l}\mathrm{O} \uparrow \\
\mathrm{P} \uparrow\end{array}$ & (Qi et al., 2008) \\
\hline $\begin{array}{l}\text { AT-MSCs } \\
\text { (Human) }\end{array}$ & $\begin{array}{l}\text { Cyclic uniaxial strain } \\
10 \%, 1 \mathrm{~Hz}, 7 \mathrm{~d}\end{array}$ & $2 \mathrm{D}$ & $\begin{array}{l}\text { Collagen } \\
\text { type I }\end{array}$ & $\begin{array}{l}\text { Decrease in } \\
\text { cell number }\end{array}$ & $\mathrm{P} \downarrow$ & (Lee et al., 2007b) \\
\hline
\end{tabular}

Identification: *, unconfined compression; A, adipogenic differentiation; AT, adipose tissue; BM, bone marrow; C, chondrogenic differentiation; D, dimensional; DBM, demineralised bone; P, proliferation; PLCL, poly(lactide-cocaprolactone); O, osteogenic differentiation; ST, sternum.

Napieralski et al., 2003). Moreover, MSCs from A2aR knockout mice express less CD73 (Katebi et al., 2009). Whether A2aR is also involved in MSC differentiation needs to be further elucidated.

Taken together, this study provides evidence that CD73 has a regulatory function in controlling the chondrogenic and osteogenic differentiation of MSCs, possibly acting as a switch by stimulating one lineage at the expense of the other. These results support earlier findings that proposed CD73 as a molecular coordinator of bone metabolism.

Compromised bone healing is hypothesised to be associated with limitation in MSC number and/or function. 
Thus, in vivo stimulation of MSC function holds great promise as a tool for cell-based therapy approaches to enhance bone repair. A prerequisite for this approach, however, is a profound understanding of the molecular mechanisms during fracture repair. Our data suggest that CD73 is a, thus far underestimated, therapeutic target to guide this regenerative process. Once, the mechanism of CD73-mediated differentiation of MSCs in the interplay with mechanical (e.g. compression) and biological (e.g. cytokines and hypoxia) stimulation is understood, specific manipulation of chondrogenesis or osteogenesis - and thereby improved bone regeneration - might be possible.

\section{Conclusion}

In conclusion, the altered CD73 expression in mechanically stimulated MSCs might link the mechanical boundary conditions to the cellular response and thereby control the bone fracture-healing outcome. Conversely, CD73 is also regulated by cytokines and growth factors, such as TGF- $\beta$, IL- $1 \beta$ and TNF- $\alpha-$ as well as conditions such as hypoxia - that are found in the haematoma during the early phase of bone healing (Cervella et al., 1993; Hunsucker et al., 2005; Thompson et al., 2004). Thus, in addition to the mechanical microenvironment, alterations in the biological microenvironment during bone healing might also account for CD73-mediated MSC behaviour. Future studies need to investigate this mechanism in biologically challenging situations, such as (1) aged patients, whose MSCs seem to harbour a lower responsiveness to mechanical stimulation, and (2) patients with pro-longed or excessive inflammatory responses, which is likely to affect CD73 expression and function and thereby MSC differentiation.

\section{Acknowledgements}

This study was supported by the Federal Ministry of Education and Research (BMBF) excellence cluster, Berlin-Brandenburg Centre for Regenerative Therapies (BCRT, Grant 0315848A). We are grateful to Dr. G. Kasper for fruitful discussions and to Dr. K. Schmidt-Bleek, L. Schumann, M. Textor and the staff of the MedicalTechnical Laboratories (Charité) for excellent technical support. We wish to confirm that there are no known conflicts of interest associated with this publication and there has been no significant financial support for this work that could have influenced its outcome.

\section{References}

Campbell JJ, Lee DA, Bader DL (2006) Dynamic compressive strain influences chondrogenic gene expression in human mesenchymal stem cells. Biorheology 43: 455-470.

Cervella P, Silengo L, Pastore C, Altruda F (1993) Human beta 1-integrin gene expression is regulated by two promoter regions. J. Biol. Chem 268: 5148-5155.
Chamberlain G, Fox J, Ashton B, Middleton J (2007) Concise review: Mesenchymal stem cells: their phenotype, differentiation capacity, immunological features, and potential for homing. Stem Cells 25: 2739-2749.

Claes LE, Heigele CA, Neidlinger-Wilke C, Kaspar D, Seidl W, Margevicius KJ, Augat P (1998) Effects of mechanical factors on the fracture healing process. Clin Orthop Relat Res 355 Suppl: S132-147.

David V, Martin A, Lafage-Proust M-H, Malaval L, Peyroche S, Jones DB, Vico L, Guignandon A (2007) Mechanical loading down-regulates peroxisome proliferator-activated receptor gamma in bone marrow stromal cells and favors osteoblastogenesis at the expense of adipogenesis. Endocrinology 148: 2553-2562.

Declercq H, Van den Vreken N, De Maeyer E, Verbeeck R, Schacht E, De Ridder L, Cornelissen M (2004) Isolation, proliferation and differentiation of osteoblastic cells to study cell/biomaterial interactions: comparison of different isolation techniques and source. Biomaterials 25: 757-768.

Delorme B, Ringe J, Gallay N, Le Vern Y, Kerboeuf D, Jorgensen C, Rosset P, Sensebe L, Layrolle P, Haupl T, Charbord P (2008) Specific plasma membrane protein phenotype of culture-amplified and native human bone marrow mesenchymal stem cells. Blood 111: 2631-2635.

Dobson KR, Reading L, Haberey M, Marine X, Scutt A (1999) Centrifugal isolation of bone marrow from bone: an improved method for the recovery and quantitation of bone marrow osteoprogenitor cells from rat tibiae and femurae. Calcif Tissue Int 65: 411-413.

Dominici M, Blanc KL, Mueller I, Slaper-Cortenbach I, Marini F, Krause D, Deans R, Keating A, Prockop D, Horwitz E (2006) Minimal criteria for defining multipotent mesenchymal stromal cells. The International Society for Cellular Therapy position statement. Cytotherapy 8: 315317 .

Goodship A, Kenwright J (1985) The influence of induced micromovement upon the healing of experimental tibial fractures. J Bone Joint Surg Br 67B: 650-655.

Huang C-YC, Hagar KL, Frost LE, Sun Y, Cheung HS (2004) Effects of cyclic compressive loading on chondrogenesis of rabbit bone-marrow derived mesenchymal stem cells. Stem Cells 22: 313-323.

Huang C-YC, Reuben PM, Cheung HS (2005) Temporal expression patterns and corresponding protein inductions of early responsive genes in rabbit bone marrow-derived mesenchymal stem cells under cyclic compressive loading. Stem Cells 23: 1113-1121.

Hunsucker SA, Mitchell BS, Spychala J (2005) The 5 '-nucleotidases as regulators of nucleotide and drug metabolism. Pharmacol Ther 107: 1-30.

Jagodzinski M, Drescher M, Zeichen J, Hankemeier S, Krettek C, Bosch U, van Griensven M (2004) Effects of cyclic longitudinal mechanical strain and dexamethasone on osteogenic differentiation of human bone marrow stromal cells. Eur Cell Mater 7: 35-41.

Jenner TL, Rose'Meyer RB (2006) Adenosine A3 receptor mediated coronary vasodilation in the rat heart: Changes that occur with maturation. Mech Ageing Dev 127: 264-273.

Jung Y, Kim S-H, Kim Y, Kim S (2009) The effects of dynamic and three-dimensional environments on 
chondrogenic differentiation of bone marrow stromal cells. Biomed Mater 4: 055009.

Kalsi K, Lawson C, Dominguez M, Taylor P, Yacoub MH, Smolenski RT (2002) Regulation of ecto-5'nucleotidase by TNF- $\alpha$ in human endothelial cells. Mol Cell Biochem 232: 113-119.

Kang M-N, Yoon H-H, Seo Y-K, Park J-K (2012) Effect of mechanical stimulation on the differentiation of cord stem cells. Connect Tissue Res 53: 149-159.

Katebi M, Soleimani M, Cronstein BN (2009) Adenosine A2A receptors play an active role in mouse bone marrow-derived mesenchymal stem cell development. J Leukoc Biol 85: 438-444.

Knippenberg M, Helder MN, Doulabi BZ, Semeins CM, Wuisman PIJM, Klein-Nulend J (2006) Adipose tissue-derived mesenchymal stem cells acquire bone celllike responsiveness to fluid shear stress on osteogenic stimulation. Tissue Eng 11: 1780-1788.

Koike M, Shimokawa H, Kanno Z, Ohya K, Soma K (2005) Effects of mechanical strain on proliferation and differentiation of bone marrow stromal cell line ST2. J Bone Miner Metab 23: 219-225.

Komatsu DE, Hadjiargyrou M (2004) Activation of the transcription factor HIF-1 and its target genes, VEGF, HO-1, iNOS, during fracture repair. Bone 34: 680-688.

Krause U, Seckinger A, Gregory CA (2011) Assays of osteogenic differentiation by cultured human mesenchymal stem cells. Methods Mol Biol 698: 215-230.

Lee W-CC, Maul TM, Vorp DA, Rubin JP, Marra KG (2007) Effects of uniaxial cyclic strain on adipose-derived stem cell morphology, proliferation, and differentiation. Biomech Model Mechanobiol 6: 265-273.

Mauck R, Byers B, Yuan X, Tuan R (2007) Regulation of cartilaginous ECM gene transcription by chondrocytes and MSCs in 3D culture in response to dynamic loading. Biomech Model Mechanobiol 6: 113-125.

Mauney JR, Sjostorm S, Blumberg J, Horan R, O'Leary JP, Vunjak-Novakovic G, Volloch V, Kaplan DL (2004) Mechanical stimulation promotes osteogenic differentiation of human bone marrow stromal cells on 3-D partially demineralized bone scaffolds in vitro. Calcif Tissue Int 74: 458-468.

Napieralski R, Kempkes B, Gutensohn W (2003) Evidence for coordinated induction and repression of ecto5 '-nucleotidase (CD73) and the A2a adenosine receptor in a human B cell line. Biol Chem 384: 483-487.

Niemela J, Henttinen T, Yegutkin GG, Airas L, Kujari A-M, Rajala P, Jalkanen S (2004) IFN-\{alpha\} Induced adenosine production on the endothelium: a mechanism mediated by CD73 (ecto-5' -nucleotidase) up-regulation. J Immunol 172: 1646-1653.

Ode A, Kopf J, Kurtz A, Schmidt-Bleek K, Schrade P, Kolar P, Buttgereit F, Lehmann K, Hutmacher DW, Duda GN, Kasper G (2011) CD73 and CD29 concurrently mediate the mechanically induced decrease of migratory capacity of mesenchymal stromal cells. Eur Cell Mater 22: 26-42.

Pelaez D, Huang C-YC, Cheung HS (2009) Cyclic compression maintains viability and induces chondrogenesis of human mesenchymal stem cells in fibrin gel scaffolds. Stem Cells Dev 18: 93-102.

Peng L, Jia Z, Yin X, Zhang X, Liu Y, Chen P, Ma K, Zhou C (2008) Comparative analysis of mesenchymal stem cells from bone marrow, cartilage, and adipose tissue. Stem Cells Dev 17: 761-773.

Qi M-C, Hu J, Zou S-J, Chen H-Q, Zhou H-X, Han L-C (2008) Mechanical strain induces osteogenic differentiation: Cbfa1 and Ets-1 expression in stretched rat mesenchymal stem cells. Int J Oral Maxillofac Surg 37: 453-458.

Regateiro FS, Howie D, Nolan KF, Agorogiannis EI, Greaves DR, Cobbold SP, Waldmann H (2011) Generation of anti-inflammatory adenosine byleukocytes is regulated by TGF- $\beta$. Eur J Immunol 41: 2955-2965.

Resta R, Thompson LF (1997) T cell signalling through CD73. Cell Signal 9: 131-139.

Rose'Meyer RB, Mellick AS, Garnham BG, Harrison GJ, Massa HM, Griffiths LR (2003) The measurement of adenosine and estrogen receptor expression in rat brains following ovariectomy using quantitative PCR analysis. Brain Res Protoc 11: 9-18.

Sekiya I, Vuoristo JT, Larson BL, Prockop DJ (2002) In vitro cartilage formation by human adult stem cells from bone marrow stroma defines the sequence of cellular and molecular events during chondrogenesis. Proc Natl Acad Sci USA 99: 4397-4402.

Song L, Webb NE, Song Y, Tuan RS (2006) Identification and functional analysis of candidate genes regulating mesenchymal stem cell self-renewal and multipotency. Stem Cells 24: 1707-1718.

Spychala J, Kitajewski J (2004) Wnt and beta-catenin signaling target the expression of ecto-5' -nucleotidase and increase extracellular adenosine generation. Exp Cell Res 296: 99-108.

Sträter N (2006) Ecto-5'-nucleotidase: Structure function relationships. Purinergic Signal 2: 343-350.

Takedachi M, Oohara H, Smith BJ, Iyama M, Kobashi M, Maeda K, Long CL, Humphrey MB, Stoecker BJ, Toyosawa S, Thompson LF, Murakami S (2012) CD73generated adenosine promotes osteoblast differentiation. J Cell Physiol 227: 2622-2631.

Thompson LF, Eltzschig HK, Ibla JC, Van De Wiele CJ, Resta R, Morote-Garcia JC, Colgan SP (2004) Crucial role for ecto-5'-nucleotidase (CD73) in vascular leakage during hypoxia. J Exp Med 200: 1395-1405.

Wang J, Thampatty BP (2008) Mechanobiology of adult and stem cells. Int Rev Cell Mol Biol 271: 301-346.

Yoshikawa T, Peel SA, Gladstone JR, Davies JE (1997) Biochemical analysis of the response in rat bone marrow cell cultures to mechanical stimulation. Biomed Mater Eng 7: 369-377. 